Aneta Lewińska

Uniwersytet Gdański

\title{
MOTYWY RELIGIJNE W KRONIKACH SZKÓŁ WIEJSKICH W LATACH 1945-1958 (NA PRZYKLADZIE KOCIEWIA I ŻUŁAW)
}

Pierwsze lata powojenne to dla wspólnoty wiejskiej czas niezwykły, pełen radości z odzyskanej niepodległości i wiary, że w wolnej Polsce życie będzie inne. I tę radość ze wspólnego działania oraz wiarę, która jak mówi polskie przysłowie, pozwala góry przenosić, odzwierciedlają ówczesne kroniki szkolne. Widać ją przede wszystkim w opisach wysiłku całej wiejskiej społeczności, która odbudowywała szkołę, wstawiała szyby, ustawiała prowizoryczne ławki, by dzieci mogły się znowu uczyć w polskiej szkole. Jak napisał kierownik szkoły w Ocyplu, Bernard Osowski:

Tutejszej ludności, pomimo że sama borykała się z trudnymi warunkami życia po przejściu frontu, chodziło o to, żeby ich dzieci pozbawione przez sześć lat szkoły polskiej znowu mogły korzystać z nauki w języku ojczystym. Pomyślano więc o przeprowadzeniu najkonieczniejszego remontu umożliwiającego rozpoczęcie normalnej nauki $(\mathrm{O}, 1945)^{1}$.

W pierwszych powojennych dniach i miesiącach radość z wolnej Polski była też radością katolików, którzy posyłali swoje dzieci do szkół z nadzieją, że otrzymają tam one wykształcenie, poznają świat spójny, chociaż dwuwymiarowy: materialny i transcendentny. Dla większości Polaków była to wówczas jedyna wizja świata. Rodzice odbudowali dla swych dzieci szkolne sale, wierząc, że w szkolnych ławkach wejdą one w świat wiedzy naukowej i zarazem w świat wiary katolickiej. Nie zapomniano jeszcze przecież na wsi strajków szkolnych

${ }^{1} \mathrm{~W}$ cytowanych fragmentach zachowano oryginalną pisownię i interpunkcję. W artykule zastosowano następujące skróty na oznaczenie badanych kronik: $\mathrm{O}$ - kronika szkoły w Ocyplu; MG - kronika szkoły w Małym Garcu; MS - kronika szkoły w Małej Słońcy; LM - kronika szkoły w Lisewie Malborskim. Karty brulionów są nieponumerowane, ale wpisy zostały umieszczone chronologicznie, dlatego dla identyfikacji miejsca cytatu w danej kronice podano rok wpisu. 
z lat 1905-1906, kiedy w obronie nauczania religii po polsku stanęły także dzieci z pomorskich wsi²; pamiętano też niedawną radość z odzyskanej niepodległości.

Analiza szkolnych kronik z kilku pomorskich wsi (Ocypla, Małego Garca, Małej Słońcy i Lisewa Malborskiego) pozwala dziś, po przeszło 70 latach, obserwować, jak gasły radość i wiara oraz jak ówczesne władze starały się zapełnić pustkę po rugowanym życiu duchowym nowymi symbolami i rytuałami. Możemy też badać, jak w wiejskich szkołach rodziła się „,nowa świecka tradycja” i jakim nowym językiem ją wyrażano.

W kronikach zamieszcza się przede wszystkim relacje z najważniejszych szkolnych wydarzeń, w tym z różnych uroczystości. W pierwszych latach powojennych odbywały się w szkole także uroczystości religijne, nierozerwalnie wplecione w rytm szkolnego kalendarza, toteż i one znajdują swoje miejsce w kronikarskiej narracji. Analiza badanych tekstów pozwala śledzić zmiany, które zachodziły w społeczności wiejskich szkół, także te, które wiązały się z narzucaniem uczniom nowego światopoglądu.

Wsie pomorskie utrwalone w zapisach szkolnych kronikarzy to swoiste mikroświaty, w których jak w soczewce skupiają się wszystkie znaki tamtego czasu. Analizując warstwę językową kronikarskich wpisów, możemy odtworzyć najważniejsze przejawy szkolnego i społecznego życia tych miejscowości.

W Ocyplu, podobnie jak w wielu innych pomorskich wsiach, nauka w budynku poniemieckiej szkoły ruszyła tuż po wyzwoleniu, na kilka tygodni przed wakacjami, już w czerwcu 1945 r. $^{3}$ Po zakończeniu drugiej wojny światowej to właśnie szkoła była najważniejszą instytucją, wokół której organizowało się powojenne życie całej wsi. W polskiej tradycji edukacyjnej, której początki wiążą się z zakonami pijarów i jezuitów, religia pozostała nieodłącznym elementem szkolnej edukacji. Obecność religii katolickiej w polskiej szkole miała w historii Polski poza światopoglądowym także wymiar patriotyczny, a w czasach zaborów jej nauka w języku polskim była obowiązkiem nie tylko katolickim, ale także patriotycznym. Religia była złączona z życiem szkoły tak ściśle, że w okresie powojennym jej losy w szkole stały się ważnym elementem kampanii politycznej wielu rządów. W powojennej Polsce władze ostatecznie usunęły ten przedmiot ze szkół w r. 1961, a jego powrót do edukacji publicznej w $1990 \mathrm{r}$. wiązał się ze zmianami politycznymi, które zaszły po r. 1989. W badanych kronikach wpisy związane z uroczystościami religijnymi są zatem świadectwem

${ }^{2}$ Por.: S. Lipski, Strajk szkolny 1900/7/1907 r. w powiecie starogardzkim, Starogard Gdański 2006; A. Bukowski, Strajk szkolny na Pomorzu Gdańskim w latach 1906-1907, „Studia i Materiały do Dziejów Wielkopolski i Pomorza” 1957, t. 3, z. 1, s. 81-110.

${ }^{3}$ Otwarcie nastąpiło 25 czerwca 1945 r. i po trzech tygodniach 14 lipca 1945 r. zakończono naukę. 
tych powojennych zmian światopoglądowych, które musiały znajdować odzwierciedlenie w dokumentach państwowej szkoły.

W niniejszym artykule analizie poddane zostaną jedynie wpisy z lat 19451958. Za datę krańcową przyjęto rok szkolny 1957/58, pierwszy po politycznej odwilży 1956 r. (ważnym znakiem przemian były: zwolnienie w październiku 1956 r. z internowania kardynała Stefana Wyszyńskiego i tym samym liberalizacja relacji państwa wobec Kościoła). Materiał językowy związany z obecnością tematyki wiary i religii w badanych kronikach w latach późniejszych, niezwykle ciekawy i bogaty, przekracza już ramy tego artykułu i znajdzie się w całościowym opracowaniu kronik szkolnych.

Wpisy kronikarzy odzwierciedlają życie społeczności szkolnej, które toczyło się według rytmu pór roku i związanego z nimi kalendarza liturgicznego. W pierwszych latach powojennych sfera sacrum w szkolnych kronikach nie tylko wiąże się z najważniejszymi świętami religijnymi, ale także jest obecna w przeżywaniu ważnych wydarzeń szkolnych, zwłaszcza początku i końca roku szkolnego, które w swojej oprawie miały msze święte. W późniejszych latach zmienia się charakter tych uroczystości szkolnych; obserwujemy laicyzację szkolnych przedstawień, również tych związanych ze świętami religijnymi. Ponownie motywy religijne znajdujemy w kronikach dopiero w latach 80 . XX w.

\section{Święta Bożego Narodzenia i Wielkiejnocy}

Najwięcej motywów religijnych jest obecnych we wpisach dotyczących najważniejszych wydarzeń liturgicznych związanych z odwieczną polską tradycją domową, społeczną i szkolną, tzn. ze świętami Bożego Narodzenia i Wielkiejnocy. W świetle badanych kronik można stwierdzić, że nawet w okresie największej komunizacji życia publicznego w szkolnej tradycji przetrwały teatralne formy związane od początków szkolnictwa z narodzinami Chrystusa. W sferze profanum w konwencji żartu mówi się o wyższości świąt Wielkiejnocy nad świętami Bożego Narodzenia ${ }^{4}$, ale mimo że liturgicznie to Wielkanoc jest najważniejszym świętem Kościoła katolickiego i to z misterium pasyjnego wywodzi się teatr, to w polskiej tradycji Boże Narodzenie ma bogatszą tradycję obrzędową, a w repertuarze szkolnych przedstawień jasełka zajmują ważniejsze miejsce niż misteria pasyjne.

${ }^{4}$ Taki tytuł nosił cykl humorystycznych wykładów radiowych Jana Tadeusza Stanisławskiego z „mniemanologii stosowanej”, prezentowany w latach 70. XX w. w Polskim Radiu (https://www.polskieradio.pl/39/156/Artykul/1755398,Jan-Tadeusz-Stanislawski--profesor-mniemanologii-stosowanej [dostęp 21.11.2017]). 
Sama nazwa święta Bożego Narodzenia pojawia się w badanych dokumentach w części objętej analizą tylko dwukrotnie, w obu wypadkach w kronice szkoły w Ocyplu. Użyta została w 1945 r. jako składnik tytułu przedstawienia $W$ noc Bożego Narodzenia $(\mathrm{O}, 1946)$ oraz po październikowej odwilży we wpisie nowym roku szkolnym 1957/58. Warto zacytować w całości tę pierwszą kronikarską relację, ponieważ jest ona jedynym zamieszczonym w czterech badanych kronikach opisem dokładnym i nasyconym motywami religijnymi:

Jasełka. W niedzielę 29 grudnia w roku szkolnym 1946/47 - odegrały dzieci szkolne na sali ob. Ropmkowskiego Teofila w Ocyplu swoje pierwsze przedstawienie gwiazdkowe. W programie znalazły się trzy punkty: Wesoła Wigilia (Komedyjka w I akcie).

W noc Bożego Narodzenia (widowisko jasełkowe).

Żywy obraz.

Tańce narodowe.

Całość przeplatały wiersze i kolędy dwugłosowe. Ludność tutejsza okazała duże zainteresowanie i wypełniła salę po brzegi. Dzieci szkolne wywiązały się ze swoich ról bardzo dobrze i otrzymały moc oklasków. Czysty dochód z przedstawienia przeznaczono na remont szkoły (O, 1946).

W tym tekście zwraca uwagę połączenie dwu stylów, mianowicie splot leksyki i frazematyki religijnej z urzędową. Znajdujemy tu czasowniki i frazy charakterystyczne dla stylistyki sprawozdań: „dzieci odegrały przedstawienie”, „W programie znalazły się trzy punkty” (OI, 1946), ale wypełnienie składniowych schematów otwieranych przez przywołane czasowniki stanowią rzeczowniki (i zestawienia) z leksyki religijnej i szkolnej tradycji przedstawień bożonarodzeniowych: przedstawienie gwiazdkowe, jasetka, widowisko jasetkowe, kolędy dwugłosowe $(\mathrm{O}, 1946)$. Listę tę uzupełniają tytuły widowisk: Wesoła Wigilia (Komedyjka w I akcie) oraz W noc Bożego Narodzenia (widowisko jasetkowe) $(\mathrm{O}, 1946)$. Takie ukształtowanie stylistyczne charakterystyczne jest dla każdej $\mathrm{z}$ badanych kronik.

Wyekscerpowany materiał leksykalny związany z Bożym Narodzeniem można uporządkować w kilku grupach tematycznych: nazwy szkolnych uroczystości organizowanych z okazji Bożego Narodzenia (w tym nazwy własne), nazwy osób związanych z Bożym Narodzeniem, nazwy podarunków oraz nazwy świątecznych dekoracji i szkolnych sposobów świętowania.

Nazwy bożonarodzeniowych uroczystości szkolnych wyekscerpowane z badanych wpisów kronikarskich zamieszczanych w ciągu kilkunastu lat powojennych odzwierciedlają zmiany światopoglądu, który narzucono szkole.

Ważnym znakiem związku z tradycją przedwojenną jest użycie nazwy jaset$k a$. Rzeczownik ten, notowany w SJPD w znaczeniu 'widowisko sceniczne lub kukiełkowe, mające za treść narodzenie Chrystusa; szopka', powszechnie się 
dziś kojarzy z dziecięcym teatrem szkolnym i przedszkolnym, ponieważ tradycja wystawiania jasełek jest w placówkach edukacyjnych nadal żywa. Jednak leksem jasetka (plur. tant./r.ż.) w tekstach z badanego czasu pojawia się tylko dwukrotnie i tylko w kronice z Ocypla - we wpisach, co znamienne, z lat 1946 i 1957. W 1946 r. nazwę tę zapisano na marginesie tekstu w funkcji tytułu kronikarskiego wpisu, wyraźnie graficznie wyodrębnionego (O, 1946), a pod r. 1957 czytamy: „W pierwsze Święto Bożego Narodzenia urządzono wieczór poezji, wystawiono jasełkę i tańce dla rodziców" (O, 1957).

Do nazw szkolnych uroczystości bożonarodzeniowych należy też leksem gwiazdka, objaśniany w SJPD m.in. jako 'uroczystość odbywająca się przy ubranym drzewku w okresie Bożego Narodzenia lub Nowego Roku, urządzana przeważnie dla dzieci i zwykle połączona z dawaniem podarunków' (zn. 3); w SJPD znaczenie to zilustrowano cytatami z 1951 r. i z Lalki Bolesława Prusa, zatem było ono znane już w XIX w. U Lindego wyraz ten występuje tylko w zn. 'godowy podarunek', z dopiskiem: „u Ewangelików tylko się zachowuje, cf. kolęda" (L).

Warto też pod względem nazw uroczystości organizowanych w szkole z okazji Bożego Narodzenia przeanalizować pełną historię bożonarodzeniowych wpisów w jednej z kronik - w kronice szkoły w Ocyplu, która najwcześniej rozpoczęła powojenną działalność. W 1946 r. ${ }^{5}$ wystawiono tam przywołane wyżej jasełka, w 1947 r. pojawia się nazwa obchód gwiazdkowy (O, 1947), a w 1949 r. uroczystość przeniesiono z grudnia na styczeń i nazwano ją już obchodem noworocznym $(\mathrm{O}, 1949)$. W wyrażeniu tym zanikają konotacje charakterystyczne dla przymiotnika gwiazdkowy, a kronikarz dodatkowo następująco wyjaśnia genezę nowej szkolnej tradycji: „Obchód noworoczny w szkole. Zgodnie z okólnikiem Kuratorium Okręgu Szkolnego Gdańskiego urządzono w dniu 8 stycznia 1949 obchód noworoczny dla dziatwy szkolnej” (O, 1949). Nową bożonarodzeniową obrzędowość tworzy się zatem na polecenie świeckich władz szkolnych. I chociaż kolejny obchód noworoczny odbył się w grudniu 1949 r., to mimo kalendarzowego paradoksu jego nazwa pozostała zgodna $\mathrm{z}$ wytycznymi kuratorium.

W następnym roku szkolnym świąteczna zabawa nosi już inną nazwę: choinka noworoczna $(\mathrm{O}, 1951)$ i odbywa się w styczniu 1951 r.; podobnie dzieje się w latach 1952 i 1953. W latach 1954 i 1955 kierownik szkoły używa określeń: przywitanie Nowego Roku (O, 9 I 1954) i powitanie Nowego Roku (O, 10 I 1955). Rok 1956 przynosi zmianę w kronikarskiej narracji: „Choinka Noworoczna. Gwiazdka dla dzieci odbyła się w tym roku w naszej szkole bardzo uroczyście” (O, 1956).

${ }^{5}$ W 1945 r. nie ma informacji o szkolnych uroczystościach z okazji świąt Bożego Narodzenia; w kronice znalazło się tylko jedno zdanie: „Ferie zimowe rozpoczęły się 22.12.1945 r. i trwały do 7.1.1946 r.” (O, 1945/45). 
Autor zastosował zatem podwójne nazewnictwo: choinka noworoczna i gwiazd$k a$. W ten sposób, nie rezygnując z zaleceń kuratorium, przywrócił dawną leksykę i religijne konotacje niesione przez rzeczownik gwiazdka, w SJPD objaśniany jako 'wigilia Bożego Narodzenia, uroczystości wigilijne' (zn. 6), a ocenienie tej uroczystości jako bardzo uroczystej podkreśla jej niezwykły charakter.

W kronice z Małego Garca sekwencja zmian nazw gwiazdkowych obchodów jest podobna. W $1946 \mathrm{r}$. autor podkreśla wagę tej uroczystości, pisząc: „22 XII urządziło tut. nauczycielstwo wraz z dziećmi pierwszą polską »gwiazdkę« (po wojnie)" (MG, 1946). Przydawki pierwsza i polska określające rzeczownik gwiazdka oraz nawiasowe dopowiedzenie po wojnie wskazują na niecodzienny charakter obchodów, a opatrzenie wyrazu gwiazdka cudzysłowem i uzupełnienie go przydawką polska podkreśla bardziej narodowy niż religijny wymiar szkolnego święta. O gwiazdce pisze kierownik szkoły jeszcze w $1947 \mathrm{r}$.

Pełna analiza wpisów do r. 1958 z czterech analizowanych kronik pozwala stwierdzić, że pojawiało się w nich kilka różnych nazw uroczystości związanych z okresem Bożego Narodzenia. Liczną grupę stanowią wyrażenia z leksemem gwiazda i jego derywatami słowotwórczymi: gwiazdka (MG, 1946, 1947; LM, 1957; O, 1957), obchód gwiazdkowy (O, 1947), przedstawienie gwiazdkowe (O, 1956), uroczystość gwiazdkowa (MG, 1947), Gwiazdka Noworoczna (LM, 1950) i obchód gwiazdkowo-noworoczny (O, 1949). Od wyrazu gwiazdka utworzono też użyte jednokrotnie określenie świątecznej przerwy szkolnej: ferie gwiazdkowe (MG, 1946).

Drugi zbiór nazw uroczystości bożonarodzeniowych stanowią struktury z członem nadrzędnym choinka: „Choinka. 26 XII 1948 urządzono »choinkę» w szkole" (MG, 1948), koszt choinki (MS, 1956), choinka noworoczna (MS, 6 I 1954, 2 I 1955; LM, 1953, 1954; MG, 1953, 1954, 1955, 1956; O, 1950, 1951, 1952, 1955, 1956), choinka szkolna (MG, 1953, 1957). Takie znaczenie tego leksemu notują słowniki, np. SJPD podaje je jako zn. 3.: 'uroczystość odbywająca się przy ubranym drzewku, w okresie Bożego Narodzenia lub nowego roku, urządzana przeważnie dla dzieci i zwykle połączona z dawaniem podarunków', a WSJP w haśle choinka również jako zn. 3. zamieszcza definicję: 'zabawa organizowana w okresie bożonarodzeniowym'. Rzadziej posługiwano się wyrażeniami z przymiotnikiem choinkowy w podrzędniku: uroczystość choinkowa (MG, 1951).

Kolejnym leksemem występującym stosunkowo często w badanym materiale obejmującym nazwy uroczystości związanych z okresem bożonarodzeniowym i noworocznym jest rzeczownik obchód. SJP PWN podaje jako jedno ze znaczeń tego wyrazu 'uroczystość', przy czym przyporządkowane zostało ono formie w lm. obchody; SJPD i WSJP notują jednak takie znaczenie również dla formy lp. - obchód. Słowo obchód wystąpiło w nazwach uroczystości szkolnych w dwu 
badanych kronikach, w połączeniu z różnymi przydawkami (dopełniaczowymi i przymiotnikowymi): obchód Św. Mikołaja - „...przed rozpoczęciem ferii zimowych odbył się w tut. szkole obchód Św. Mikołaja i gwiazdki" (LM, 1947); obchód gwiazdkowy w szkole (O, 1947); obchód noworoczny w szkole (O, 1949); obchód gwiazdkowo-noworoczny w szkole (O, 1949).

Pojedynczo wystąpiła konstrukcja współrzędna łączna Mikołaj i Gwiazdka: „20 XII 47 Mikołaj i Gwiazdka. W niedzielę przed rozpoczęciem ferii zimowych odbył się w tut. szkole obchód Św. Mikołaja i gwiazdki” (LM, 1947).

Jak wynika z powyższego zestawienia nazw uroczystości szkolnych organizowanych w czasie Bożego Narodzenia i Nowego Roku, najczęściej używano w tym znaczeniu wyrażenia choinka noworoczna (13 razy). Określenie to przyjęło się we współczesnym języku polskim na tyle, że po wpisaniu w wyszukiwarkę Google kolokacji choinka noworoczna w szkole uzyskujemy 906 wyników, a w wypadku wyrażeniu choinka noworoczna - aż 17,3 tys. wyników.

Analiza wpisów kronikarskich do r. 1957 pozwala też zaobserwować, jak kronikarze tworzyli wrażenie ciągłości bożonarodzeniowej tradycji szkolnej. Wprowadzali w tym celu do tekstu leksemy ewokujące cykliczność opisywanej czynności, mianowicie przymiotnik coroczny: „W tym roku na coroczną »Choinkę« zorganizowaną przez PWRN w Gdyni-Grabówku pojechało z naszej szkoły 8 uczniów..." (MG, 1955); a także wyrażenia: corocznym zwyczajem: „Corocznym zwyczajem odbyła się 6 stycznia choinka noworoczna z bogatym programem artystycznym” (MG, 1954); dorocznym zwyczajem: „Dorocznym zwyczajem została zorganizowana »Choinka noworoczna«...” (MG, 1956), „Dorocznym zwyczajem zorganizowano szkolną choinkę” (MG, 1957).

Choinkom noworocznym towarzyszy też zabawa rodziców, ale określenie to pobawione jest konotacji religijnych, np. „Choinka Noworoczna... W tym dniu odbyła się też zabawa rodziców" (MG, 1955).

W kronice z Małego Garca zwraca uwagę indywidualna skłonność kronikarza do stosowania cudzysłowów, używanych w funkcji wyodrębniania nazw własnych pisanych albo małą, albo dużą literą, np. ,, Choinka Noworoczna” (MG, 1955), ale „Choinka noworoczna” (MG, 1956).

Widać też w badanych kronikach zróżnicowanie stylistyczne związane z indywidualnymi upodobaniami autorów, np. w Ocyplu występuje częściej obchód noworoczny, a w Małym Garcu - choinka noworoczna.

Obok wyrazów pospolitych w kronikach występują nazwy własne szkolnych uroczystości noworocznych i gwiazdkowych. Są to nazwy przedstawień związanych tematycznie z biblijnym wydarzeniem narodzin Jezusa Chrystusa, np. 1. Wesoła Wigilia (Komedyjka w I akcie)”, ,,2. W noc Bożego Narodzenia (Widowisko jasetkowe) (O, 1946), „Odegrana została sztuczka sceniczna »Św. Mikołaj«" (LM, 1947). Później scenki o wigilijnym wieczorze zastąpiono m.in. wystawieniem ,przedstawienia pt. »Urządzamy wieczór noworoczny«” 
(MS, 1954). Kilka nazw własnych świadczy o tym, że odgrywano również w czasie tych uroczystości utwory dalekie od nastroju świątecznego, zimowego czy noworocznego. We wpisie z r. 1953 zamieszczonym w kronice w Małym Garcu czytamy: „Między innymi odegrano »Siedmiomilowe buty «- Brzechwy” (MG, 1953). W innej szkole uroczystość wypełniły: „Deklamacje uczniowskie wierszy o choince, zimie, pracy, planie 6-letnim. Deklamacje były przeplatane śpiewem uczniów klas V i VI (Hymn młodzieży, My jesteśmy mali przodownicy, Piosenka o Nowej Hucie, Walczyk murarski i in.)” (MS, 1954). W Ocyplu prelegent wygłosił przemówienie, w którym wystąpiła nazwa własna niezwiązana nawet ze światem dziecięcym czy młodzieżowym: „W dalszym ciągu swego przemówienia zapoznał prelegent zebranych z wielkimi zamierzeniami Polski Ludowej w »Planie Sześcioletnim«" $(\mathrm{O}, 1949)$.

Nazwy osób związanych z Bożym Narodzeniem to druga interesująca grupa leksykalna wyodrębniona w badanym zbiorze szkolnych narracji, pozwalająca obserwować, jak w języku kronik odbija się narzucany nowy światopogląd, obowiązujący w powojennej szkole.

W tradycji jasełkowej głównymi bohaterami są postacie biblijne: św. Józef, Maryja, nowo narodzony Chrystus, których jednak w badanych tekstach nie znajdziemy. Kronikarskie informacje o przedstawieniach jasełkowych, a później zabawach gwiazdkowych i noworocznych ograniczają się do wymienienia tytułów części uroczystości i opisu (mniej lub bardziej szczegółowego) przebiegu tego szkolnego wydarzenia. Najczęściej występuje w nich tylko jedna postać stereotypowo wiązana ze szkolnymi uroczystościami organizowanymi na przełomie roku: Święty Mikołaj. O św. Mikołaju czytamy w kronice z Lisewa Malborskiego, w której wyrażenie to znalazło się w tytule uroczystości i tytule przedstawienia: Mikołaj i Gwiazdka: „20 XII 1947 W niedzielę przed rozpoczęciem ferii zimowych odbył się w tut. szkole obchód Św. Mikołaja i Gwiazdki... Odegrana została sztuczka sceniczna »Św. Mikołaj«...” (LM, 1947). Mikołaj odwiedzał też dzieci w Małym Garcu i w Ocyplu: „Mikołaj obdarował każde dziecko torebką ciastek i upominkami...” (MG, 1946); „Po części artystycznej przybył »Mikołaj« z podarunkami. Obdarował każde dziecko upominkiem..." (MG, 1948); „... szczególnie pojawienie się Mikołaja z podarunkami było przez dzieci radośnie przyjęte...” (MG, XII 1957); „W dniu 24. XII 57 św. Mikołaj, którym był człowiek 66-letni Jan Kwaśniewski, obdarował dziatwę »gwiazdką«...” (O, 1957); „12 I 1958 ...Punktem kulminacyjnym uroczystości było przybycie świętego Mikołaja (Majkowa w pomysłowym kostiumie) z koszami podarków" (MS, 1958).

W badanych kronikach wystąpiła też inna nazwa tej postaci, mianowicie gwiazdor: „Przy choince odśpiewano kilka kolęd, poczem »gwiazdor« obdarował każde z dzieci torebką ciastek” (MG, 1947), „Pod koniec uroczystości zjawił się gwiazdor, który wręczył każdemu z dzieci paczkę...” (O, 1947), „...wtedy 
nastąpiła wielka niespodzianka, gdyż przyszedł gwiazdor i obdarzył wszystkie dzieci paczkami” $(O, 1956)$. SJP PWN notuje ten wyraz z kwalifikatorem reg. i definicją 'odpowiednik Świętego Mikołaja', a WSJP wyjaśnia: 'postać rozdająca prezenty w okresie Bożego Narodzenia', przy czym w informacjach o użyciu czytamy: „Zapisywane również wielką literą”. W analizowanych wpisach znajdziemy obie pisownie. Rzeczownik gwiazdor jest nazwą regionalną, nie dziwi zatem jego wystąpienie na kartach kronik wiejskich szkół.

Przywołane cytaty poświadczają użycie nazw Mikołaj / św. Mikołaj i gwiazdor w latach 1946 i 1948 oraz powtórnie dopiero w latach 1957 i 1958. Dziesięcioletnia przerwa w obecności Mikołaja w kronikach wiąże się z zamianą $s ́$ w. Mikołaja i gwiazdora na Dziada//Dziadka Mroza, którego odwiedziny w szkole po r. 1948 opisano w trzech z czterech badanych kronik. Czytamy o tym w kronice z Ocypla: „Po występach artystycznych przyszedł Dziad Mróz, który obdarował dzieci szkolne słodyczami i przyborami szkolnymi przygotowanymi przez Komitet rodzicielski” (O, 1955); z Małego Garca: „Także bogato obdarował dzieci naszej szkoły »Dziad Mróz« na choince zorganizowanej przez miejscowy Komitet Rodzicielski” (MG, 1956); z Małej Słońcy: „Program uroczystości obejmował... rozdawania podarunków przez Dziadka Mroza" (MS, 1956). Postać Dziadka Mroza, wprowadzona - wzorem Związku Radzieckiego - jako świecki odpowiednik św. Mikołaja, w badanych kronikach obecna jest tylko w latach największego nacisku władzy na laicyzację szkoły; w 1957 r. do szkół powrócił św. Mikołaj.

Nazwy podarunków to kolejny ważny zbiór leksemów związanych z tradycją obdarowywania się w wigilijny wieczór. Ten zwyczaj także został w szkole zlaicyzowany, a kronikarze dają tego świadectwo, opisując rozdawanie podarunków w czasie szkolnych uroczystości. Interesujące są nazwy produktów wręczanych dzieciom w paczkach przez św. Mikołaja, gwiazdora czy Dziada Mroza oraz konteksty ich użycia. Były to nazwy o różnym zakresie znaczeniowym, reprezentujące kilka pięter podrzędności. Do nazw ogólnych należą podarunek/ podarek i paczka: „W tej części dużo radości wywołało pojawienie się »Dziada Mroza« z podarunkami” (MG, 1953), „Następnie dzieci otrzymały podarki noworoczne..." (O, 1954). Nazwy szczegółowe pojawiają się w szeregach wyliczeń, np.: „W paczkach były cukierki, ciastka, piernik i przybory szkolne” (MS, 1954). Leksemy paczka i podarunek kojarzą się z różnymi świętami, nie tylko religijnymi, ale przydawka noworoczna przywołuje czas szkolnych ferii z okazji Bożego Narodzenia. Podobne konotacje można przypisać niektórym nazwom zawartości paczek, np. piernik w świetle zapisów w WSJP w zakładce Połaczenia to przede wszystkim „świąteczny, tradycyjny piernik"6. Również inne nazwy

${ }^{6} \mathrm{http}: / /$ www.wsjp.pl/index.php?id_hasla=23044\&id_znaczenia=2514386\&l=20\&ind= 0 [dostęp: 21.11.2017]. 
w zestawieniu z kontekstem opisu szkolnych uroczystości choinkowych ewokują atmosferę rodzinnego świętowania narodzenia Chrystusa utrwaloną w polskiej tradycji, kiedy dzieci obdarowywano ciastkami i cukierkami. Najpełniej ten świąteczny zwyczaj wręczania prezentów oddaje opis szkolnej gwiazdki w kronice ocypelskiej: „Pod koniec uroczystości zjawił się gwiazdor, który wręczył każdemu z dzieci paczkę z piernikami, jabłuszkami, cukierkami i przyborami szkolnymi. w czasie przerw i rozdawania paczek odegrała miejscowa orkiestra kolędy" (O, 1947).

Można również uznać, że czasownik obdarowat, zestawiony z leksemem nazywającym wykonawcę tej czynności: św. Mikołaj lub gwiazdor, wywołują kontekstowo konotacje religijne, ale w opisach pojawiają się też znaki laicyzacji tej postaci. Kronikarze wyjaśniają m.in., kto odgrywał rolę św. Mikołaja, np.: „W dniu 24. XII 57 Św. Mikołaj, którym był człowiek 66-letni Jan Kwaśniewski, obdarował dziatwę »gwiazdką«. Każde dziecko otrzymało słodyczy na 15 złotych" (OI, 1957/58), albo dodają, kto te upominki ufundował lub/i ile kosztowały. W relacjach z uroczystości gwiazdkowych pojawiają się więc wyrazy, które znoszą sakralny wymiar świąt: koszta, spółdzielnia produkcyjna, dary PCK, fundusze gminy, Komitet Rodzicielski, np. „Koszta uroczystości wyniosły 1119 złotych, które pokrył Komitet rodzicielski z darów spółdzielni produkcyjnych i dobrowolnych datków rodziców” (MS, 1955), „Komitet Rodzicielski przygotował dla wszystkich uczniów paczki ze słodyczami, przybory szkolne i książki. Koszta urządzenia choinki wyniosły ok. 900 złotych" (M, 1953). Paczki ze słodyczami rozdawane przez przebranego mikołaja, zapłacone z funduszów gminy lub pochodzące z darów Polskiego albo Amerykańskiego Czerwonego Krzyża, stają się zatem tylko namiastką atmosfery religijnego wspomnienia biskupa Mikołaja, który rozdawał podarki ubogim dzieciom. Z religijnym wymiarem szkolnej uroczystości nie harmonizuje przede wszystkim wyrażenie fundusze gminy, bo jednak kolokacje darów PCK i Czerwonego Krzyża bardziej wiążą się z ideą świątecznego obdarowywania się niż fundusze gminy ukonkretnione w opisie liczbą złotych.

Nazwy świątecznych dekoracji i szkolnych sposobów świętowania czasu Bożego Narodzenia wynotowane z badanego materiału leksykalnego przywołują symbolikę religijną tylko w niewielkim zakresie. Niewątpliwie konotacje religijne ma leksem kolęda. Kronikarze piszą o śpiewaniu kolęd przy choince w latach 1946 i 1947: „Całość przeplatały wiersze i kolędy dwugłosowe” $(\mathrm{O}, 1946)$, ,Odegrana została sztuczka sceniczna »Św. Mikołaj« ze śpiewem kolęd przy udziale wszystkich zebranych” (LM, 1947), „Przy choince odśpiewano kilka kolęd” (MG, 1947), „Przy zapalonej choince dzieci odśpiewały kolędy” $(\mathrm{O}, 1947)$. W kolejnych latach nie tylko nie ma już w kronikach wzmianek o kolędach, ale ich miejsce zajęły utwory o tematyce świeckiej: „Następnie dzieci popisywały się występami artystycznymi o tematyce świeckiej” (O, 1950), 
podano też dokładniejsze informacje o tematyce tych tekstów: „Następnie dzieci popisywały się tańcami, odśpiewały kilka pięknych piosenek i wygłosiły piękne wierszyki o pracy" (O, 1949). Kolędy zostały zastąpione przez wierszyki i piosenki. Jednak największym znakiem laicyzacji jest zamiana kolęd na przemówienie, która ujawnia się nie tylko we wprowadzeniu do kronikarskiego opisu nazw gatunków wypowiedzi obcych tradycjom świątecznym (jak przemówienie), ale też w stosowaniu w nim stylu powojennej propagandy, np.: „W dalszym ciągu swego przemówienia zapoznał prelegent zebranych z wielkimi zamierzeniami Polski Ludowej w »Planie Sześcioletnim«” (O, 1949), „Przemówienie kierownika szkoły o osiągnięciach Polski Ludowej w r. 1953 i planach na rok 1954” (MS, 1953), „Program uroczystości obejmował: przemówienie noworoczne kierownika szkoły” (MS, 1956).

Powrót leksemu kolęda odnotowujemy dopiero we wpisach z roku szkolnego 1957/58, przy czym autorzy ujawniają świadomość odpowiedzialnej za to zmiany politycznej, dodając dopowiedzenie po raz pierwszy od kilku lat: „W czasie zabawy przy choince dzieci śpiewały - po raz pierwszy od kilku lat - kolędy" (MS, 1957). Świadomie stosują też wyrażenie polskie kolędy, ewokujące polską tradycję bożonarodzeniową: ,a później wszyscy zebrani śpiewali polskie kolędy” (O, 1957).

Wielkanoc w polskiej tradycji szkolnej nie ma tak rozbudowanej obrzędowości jak Boże Narodzenie, ale w początkowym okresie działalności teatrów szkolnych wystawiano w nich również misteria pasyjne ${ }^{7}$. W pierwszych powojennych wpisach do kronik szkół wiejskich niemal nie ma wzmianek o tym najważniejszym katolickim święcie. Jeden raz pojawia się nazwa Święta Wielkanocne, jednak jedynie jako miara czasu: „Po świętach Wielkanocnych przybyły do szkoły 3 Smolicówny. Od 13 XI 52 przebywały w Domu Dziecka” (MS, 1953).

Święta te zostały przywołane także w nazwie ferii wielkanocnych (8 użyć w badanych 4 kronikach) oraz w określeniu jednego z dni Wielkiego Tygodnia: wielkanocny czwartek (1 raz; O, 1947). Wyrażenie ferie wielkanocne pojawia się jeszcze w latach 50. XX w., niekiedy zastępowane przez ferie wiosenne, ale nie ma tu konsekwentnej laicyzacji jak w zamianie świętego Mikołaja na Dziadka Mroza.

${ }^{7}$ Teatr szkolny rozwijał się od czasu sprowadzenia w 1564 r. jezuitów do Polski. Wystawiano sztuki o tematyce biblijnej, w tym misteria pasyjne (http://www.encyklopediateatru.pl/hasla/281/teatr-jezuicki; I. Kadulska (oprac.), Teatr jezuicki XVIII i XIX wieku w Polsce. Z antologia dramatu, Gdańsk 1997.). Współcześnie - na podstawie licznych zasobów szkolnych stron internetowych - można dostrzec powrót tradycji szkolnych przedstawień pasyjnych. 
Pojedynczo wystąpiło natomiast wyrażenie rekolekcje w kościele, konotujące religijne przeżywanie świąt Wielkiejnocy: „27-28 II. W klasach III-IV-V nie było lekcji. Dzieci miały rekolekcje w kościele" (MS, 1953).

\section{Msze i nabożeństwa związane ze świętami kościelnymi, szkolnymi i świeckimi}

Zapoczątkowana $\mathrm{w}$ jezuickich szkołach tradycja wiązania życia szkoły z rokiem liturgicznym oraz nadawania szkolnym uroczystościom wymiaru sakralnego poprzez uczestnictwo młodzieży w mszach przetrwała do dziś także w szkołach świeckich. Z Encyklopedii teatru polskiego dowiadujemy się, że „[w] szkołach prowadzonych przez Towarzystwo Jezusowe organizowano spektakle mające uświetniać szkolne uroczystości, obchody świąteczne (szczególnie uroczystość Bożego Ciała) czy wizyty dostojnych gości"8.

Święta szkolne. W kronice z Ocypla zakończenie pierwszego powojennego roku szkolnego uczczono specjalnym nabożeństwem, w którym wspólnie uczestniczyli nauczyciele i uczniowie:

Zakończenie roku szkolnego. Dnia 28 czerwca 1946 r. zakończono naukę w szkole, a następnego dnia udali się nauczyciele wraz z dziatwą szkolną na nabożeństwo do kościoła parafialnego w Lubichowie. Po południu odbyła się uroczystość pożegnania murów szkolnych przez młodzież opuszczającą szkołę w liczbie 31 (O, 1946).

Nabożeństwo odbyło się przed rozdaniem świadectw. Również nowy rok szkolny 1946/47 rozpoczęto w Ocyplu wspólną mszą. Pod datą 3 września kronikarz zapisał: „W tym dniu udali się nauczyciele wraz z dziećmi szkolnymi na mszę świętą do kościoła parafialnego w Lubichowie" (O, 1946).

W 1947 r. kierownik szkoły w Ocyplu informował o przygotowanej dla uczniów zabawie na zakończenie roku szkolnego:

Zabawa szkolna...W nagrodę za całoroczny trud urządziło grono nauczycielskie w porozumieniu z Opieką Rodzicielską w dniu 15 czerwca 1947 r. zabawę szkolną w lesie koło dworca kolejowego... O godz. 10-tej pieśnią „Wszystkie nasze dzienne sprawy” zakończono tę miłą imprezę szkolną (O, 1947).

W sprawozdaniu tym nie ma wzmianki o mszy świętej, ale mowa w nim o zakończeniu szkolnej imprezy wspólnym odśpiewaniem pieśni religijnej, wy-

${ }^{8}$ http://www.encyklopediateatru.pl/hasla/281/teatr-jezuicki [dostęp 21.11.2017]. 
konywanej tradycyjne na zakończenie wielu świeckich zabaw, także weselnych. W tekście o zakończeniu roku szkolnego 1947/48 ponownie czytamy o wspólnym uczestnictwie nauczycieli i dzieci we mszy świętej w parafii w Lubichowie:

W tym dniu udali się nauczyciele z dziatwą szkolną na mszę świętą do kościoła parafialnego w Lubichowie. Po nabożeństwie szkolnym zebrała się dziatwa wszystkich szkół gminy Lubichowo na dziedzińcu szkolnym szkoły Lubichowo, by wysłuchać przemówienia ministra oświaty dra Stanisława Skrzeszewskiego do młodzieży szkolnej z okazji rozpoczęcia roku szkolnego $(\mathrm{O}, 1948)$.

Także w Małym Garcu zakończenie roku szkolnego 1947/48 miało wymiar sakralny. W tym wypadku kronikarz pisze o nabożeństwie: „Zakończenie roku 47/48. Uroczystość odbyła się w Subkowach: nabożeństwo i występy szkół i gminy" (MG, 1948).

W przywołanych notatkach wystąpiły dwa leksemy: nabożeństwo i msza święta. Wielki stownik języka polskiego definiuje nabożeństwo jako 'obrzęd polegający na oddawaniu czci Bogu przez wspólne modlitwy wiernych’, a mszę objaśnia jako 'najważniejszą ceremonię liturgiczną w Kościołach chrześcijańskich ustanowioną przez Chrystusa na pamiątkę Ostatniej Wieczerzy’ (WSJP). Trudno jednoznacznie ustalić, czy autorzy kronik używali tych leksemów wymiennie, czy też pisali o innych obrzędach. Kontekst z kroniki ocypelskiej z 1948 r. zdaje się wskazywać na synonimiczne traktowanie obu tych nazw, ponieważ wystąpiły one w dwu zdaniach dotyczących tego samego wydarzenia liturgicznego.

$\mathrm{W}$ analizowanych tekstach informacje o okolicznościowych mszach i nabożeństwach organizowanych w parafiach Subkowy i Lubichowo z okazji rozpoczęcia czy zakończenia roku szkolnego znajdujemy tylko w pierwszych latach powojennych, do r. 1949. Później w kronikach szkolnych odbija się narzucony odgórnie rozdział kościoła i szkoły. Trudno powiedzieć, czy mszy już dla uczniów nie organizowano, czy tylko kronikarze tych informacji w dokumentach szkolnych nie zamieszczali.

Święta religijne. W badanych tekstach tylko jedna wzmianka dotyczy szkolnej akademii związanej ze świętem wiary - obchodami ku czci Najświętszego Serca Jezusowego, upowszechnionymi w Kościele w XIX w. ${ }^{9}$ :

W szkole 6 VI 1948 Akademia ku czci Serca Jezusowego. Druga akademia urządzona przez nauczycielkę Damuć Walerię z Kółkiem różańcowym miała charakter podobny co i akademia ku czci Matki Boskiej. Program tej akademii zawierał dwadzieścia pięć punktów. Licznie zebrani rodzice

${ }^{9}$ Por.: https://opoka.org.pl/biblioteka/T/TA/TAL/ur_nspj.html [dostęp 21.11.2017]. 
wraz z księdzem złożyli serdeczne podziękowania koleżance za jej pracę nad wychowaniem moralnym dziatwy (LM, 1948).

W przytoczonym fragmencie pojawiają się jeszcze inne nazwy o charakterze religijnym: Matka Boska i kótko różańcowe, świadczące o tym, że w życiu szkoły święta wiary też zajmowały ważne miejsce.

Święta lokalne i państwowe o charakterze świeckim uroczyście obchodzone przez społeczność szkolną miały w świetle badanych kronik wymiar religijny jeszcze w latach 40. XX w. We wszystkich kronikach z tego okresu przeczytamy o mszy czy nabożeństwie odprawionych z okazji 1 i 3 maja: „1, 2, 3 maja wolne od nauki jako święta narodowe. Uroczystości obchodzono w klasie. 3. maja poświęcony książce polskiej i zbierano datki na ten cel ${ }^{10}$. Szkoła brała udział w nabożeństwie i akademii w Subkowach” (MG, 1946); „1 V 48. Cała młodzież szkolna z chorągiewkami wzięła udział w nabożeństwie, wiecu i ogólnym pochodzie, a na uroczystej akademii..." (LM, 1948). W kronice z Małego Garca podobna informacja o uroczystym i sakralnym wymiarze celebrowania Święta Pracy ma trochę inne ukształtowanie stylistyczne:

1 maja Święto Pracy obchodzono w ramach gminy w Subkowach na pięknie udekorowanych wozach udała się młodzież szkolna i starsi do Subków. Brano udział w nabożeństwie, defiladzie, wysłuchano przemówień. Każdej szkole wręczono jako dar piłkę do siatkówki (MG, 1948).

W przywołanym tekście zwraca uwagę wyliczenie w jednym ciągu wyrazów pochodzących z różnych rejestrów stylistycznych i należących do innych pól tematycznych: nabożeństwo (pole tematyczne religii) i defilada, przemówienia (pole tematyczne polityki). W leksemach tych uobecniają się wszystkie kształtowane w ówczesnej szkole wartości: związane z Kościołem i wiarą (jeszcze w pierwszych latach powojennych obecne w szkole) oraz narzucane przez nową władzę: socjalistyczny patriotyzm i sport.

W 1948 r. i później nie ma już w kronikach wzmianki o nabożeństwie odprawianym z okazji majowych świąt. W sprawozdaniach z tych uroczystości mowa jedynie o świeckich formach obrzędowości: ,śpiewy, deklamacje i przemówienia”, „gminne defilady i akademie w gminie” (MG, 1948). W 1950 r. opis obchodów 1 maja w Małej Słońcy zajmuje całą stronę kroniki i kończy się zna-

${ }^{10}$ Warto zwrócić uwagę na zamianę narodowego charakteru wspomnienia Konstytucji 3 maja na święto książki i czytelnictwa. Święta Oświaty, przypadające na 1-3 maja, ustanowiono uchwałą rady Ministrów 22 marca 1946 r., przyjęcie tej daty uzasadniając nawiązaniem do prac KEN i demokratycznych reform Konstytucji 3 maja (por.: https:// repozytorium.umk.pl/bitstream/handle/item/1625/Swieto\%20oświaty\%20popraw.pdf?sequence=1). 
miennym dla nowej stylistyki podsumowaniem: „Ogólna radość i zadowolenie nie miało granic" (MG, 1950).

Tylko raz wystąpił w badanych tekstach leksem poświęcić, definiowany przez słownik jako 'powierzyć opiece Bożej zwierzęta, przedmioty, żywioły, poprzez odmówienie stosownych modlitw i pokropienie ich wodą święconą' (WSJP). Użył go autor kroniki z Lisewa Malborskiego, kiedy relacjonując uroczyste otwarcie odbudowanego mostu wiślanego, z patosem pisał: „Leczymy rany zadane przez germańskiego najeźdźcę. Dnia 8 III 47 roku nastąpiło poświęcenie i otwarcie mostu kołowego, (pasażerskiego), łącząc tym samym Tczew - Pomorze z Lisewem - Malborgiem" (LM, 1947).

W późniejszych notkach z badanego okresu nie znajdujemy już wzmianek o religijnym wymiarze nadawanym świeckim świętom państwowym czy lokalnym.

\section{Księża i kościól}

Motywy religijne pojawiają się w szkolnych kronikach - jak wynika z całego wcześniejszego opisu - przede wszystkim w związku z uroczystościami szkolnymi, które towarzyszyły świętom religijnym lub które były uświetniane przez uroczystości religijne. Rzadziej używano słownictwa religijnego w opisach codziennego życia szkoły. Pojedyncze wzmianki tego rodzaju dotyczą lekcji religii, o których jednak wspomina się w kronikach tylko w kontekście objęcia tego przedmiotu przez nowego nauczyciela. Przy tej okazji kronikarze wprowadzają do sprawozdań z działalności szkoły leksemy katecheta i ksiądz (też w skrótowym zapisie $k s$.). Takie wzmianki znalazły się w trzech z czterech badanych dokumentów szkolnych, por.:

Po krótkiej przerwie wznowiono naukę religii ${ }^{11} \mathrm{w}$ naszej szkole. Katechetą jest Ksiądz Marszall z Lubichowa (O, 1956/57)

20.I Nauka religii. Poczynając od dnia dzisiejszego nauki religii w szkole będzie udzielał ks. Sadowski Kazimierz z Subków (MS, 1953)

Wiśniewska Jadwiga - naucz. religii płatna od godzin (LM, 1950).

O niektórych aspektach życia religijnego pisano też w kronikach szkolnych - choć raczej rzadko - bez bezpośredniego związku z życiem szkoły. W latach

${ }^{11}$ Od 1949 r. władze zezwalały na nieprowadzenie lekcji religii w szkole, w 1956 r. religia stała się przedmiotem nadobowiązkowym, a w 1961 r. Sejm - ustawą - definitywnie usunął ten przedmiot ze szkoły (https://opoka.org.pl/biblioteka/T/TA/TAK/historia_katechezy.html [dostęp 21.11.2017]). 
tużpowojennych stosunkowo często wspominano zwłaszcza rolę kościołów i księży w różnych wydarzeniach ważnych dla lokalnej społeczności.

Na przykład Józef Rembowski, niezwykle patetycznie opisujący we wstępie do kroniki szkoły w Lisewie Malborskim radość z odzyskanej wolności, zawarł w niemal poetyckiej apostrofie do szkolnego dokumentu m.in. fragment dotyczący kościołów:

Stare kościoły gotyckie sterczą dziwacznie wysokimi spiczastymi wieżami, wznosząc modły dziękczynne do Boga za odzyskaną wolność (LM, 1945).

Warto przy okazji zauważyć, że poetyckie walory cytowanego uosobienia (przypisującego kościołom zdolność modlitwy) kreują też inne leksemy z pola semantycznego religii: apelatyw modty oraz teonim Bóg.

Również zaraz po wyzwoleniu zaczęto krzewić pamięć o pomordowanej podczas II wojny światowej polskiej inteligencji, w tym o kapłanach. Już we wstępie do kroniki szkoły w Ocyplu jej kierownik, Bernard Osowski, przypomniał tragiczne wojenne wydarzenia, m.in. prześladowania księży:

Sześcioletni okres okupacji niemieckiej to okres największych prześladowań, aresztowań i mordów dokonywanych na niewinnych Polakach. Niemiec, chcąc całkowicie i bezpowrotnie wytępić wszystko co polskie, starał się przede wszystkim usunąć polską inteligencję, zwłaszcza tych, którzy wszczepili tego ducha polskiego u dzieci, a więc księży i nauczycieli $(\mathrm{O}, 1945)$.

W pierwszych latach powojennych ważnym wydarzeniem w życiu społeczności wiejskiej i szkolnej były ekshumacje osób pomordowanych przez hitlerowców, zwłaszcza miejscowych nauczycieli i księży. O takim wydarzeniu Wiktor Koślicki napisał już na drugiej stronie kroniki szkoły w Małym Garcu:

Dnia 21 3. odbyła się ekshumacja zwłok zamordowanego ks. proboszcza Szulca. Ks. proboszcz długoletni duszpasterz parafii Subkowy, osadzony przez hitlerowców w Stutthofie, gdzie tam życie swoje oddał (MG, 1946).

W przytoczonym fragmencie słownictwo religijne używane jest w sposób naturalny. Zastosowane przez autora zwyczajowe wyrażenia ks. proboszcz i duszpasterz parafii Subkowy współgrają z tematyką notatki. 


\section{Wnioski}

Motywy religijne w analizowanych kronikach szkolnych z lat 1945-1958 występują przede wszystkim we wpisach związanych ze szkolnymi obchodami świąt, a zwłaszcza Bożego Narodzenia. Pozostałe opisane w kronikach obszary szkolnej działalności tylko w niewielkim stopniu nawiązują do religijnego wymiaru życia ówczesnej wsi. W dokumentach sporządzanych przez pracowników szkoły w latach 1945-1957 odbija się laicyzacja edukacji, chociaż szkoła i kościół oraz nauczyciel i proboszcz to od wieków instytucje najważniejsze w życiu społeczności wiejskiej. Zapewne nie utraciły one swej pozycji również po 1945 r., po wprowadzeniu nakazu ateizacji nauczania.

Kierownicy szkoły, wiedząc, że kroniki czytają także wizytatorzy, prawdopodobnie świadomie kształtowali swoje wpisy tak, by oddawały pożądany przez władze kierunek przemian. Dokładna analiza języka kronik pozwala jednak dostrzec zarówno celowość wprowadzania informacji o wypełnianiu nowej misji szkoły, jak i przebijające się w niektórych wpisach przekonanie o nienaturalności takiej sytuacji. Prawdopodobnie autor szkolnego dokumentu z rozmysłem informował, że „dzieci popisywały się występami artystycznymi o tematyce świeckiej” (O, 1950), ale jednocześnie znajdziemy w tej kronice odzwierciedlenie jego tęsknoty za utrwalonym w polskiej kulturze związkiem szkoły z sacrum. Zapewne wyrazem tego przekonania jest przydawka pierwsze, por.: „swoje pierwsze przedstawienie gwiazdkowe" $(\mathrm{O}, 1946)$, wprowadzona do wpisu z 1946 r., aby wyrazić niezwykłość przedstawienia odegranego w pierwszą gwiazdkę po zakończeniu wojny. Podobną funkcję pełni pojawiające się w innej kronice wyrażenie po raz pierwszy od kilku lat, zastosowane w odniesieniu do powrotu śpiewania kolęd na szkolnych choinkach: „W czasie zabawy przy choince dzieci śpiewały - po raz pierwszy od kilku lat - kolędy" (MS, 1957); ten odautorski komentarz można uznać za swoisty wykładnik niedopowiedzianej radości z powrotu tradycji religijnych do szkół.

Motywy religijne obecne są $\mathrm{w}$ analizowanych tekstach przede wszystkim poprzez wprowadzanie leksyki religijnej lub - znacznie częściej - leksyki jedynie o konotacjach religijnych. Niewiele znalazło się w analizowanym materiale słownikowym wyrazów o pochodzeniu biblijnym, pojedyncze są użycia nazw postaci z Pisma św. i tyko kilkakrotnie użyto słów odnoszących się do struktury i działalności Kościoła, np. ksiądz, proboszcz, parafia, msza, nabożeństwo. Bogatszy jest materiał leksykalny związany z obrzędowością świąt Bożego Narodzenia. Właśnie analiza tego zbioru leksykalnego pozwala obserwować, jak język stał się narzędziem politycznej laicyzacji świąt religijnych, gdy kolędy zamieniono najpierw na świeckie wierszyki lub piosenki o pracy, a potem na przemówienia prelegenta, a Świętego Mikołaja zastąpił Dziadek Mróz, przychodzący już nie w czasie grudniowych świat, ale w dniu szkolnego obchodu noworocznego. 
Kroniki wiejskich szkół z pierwszego powojennego dwunastolecia są zatem świadectwem kształtowania się nowej szkolno-urzędowej odmiany języka, która mimo swojej nadrzędnej funkcji propagandowej pozwala po latach odczytać wpisany w te teksty obraz ówczesnego życia także w jego wymiarze religijnym ${ }^{12}$.

\section{Bibliografia}

Bukowski A., Strajk szkolny na Pomorzu Gdańskim w latach 1906-1907, „Studia i Materiały do Dziejów Wielkopolski i Pomorza” 1957, t. 3, z. 1.

Doroszewski W. (red.), Stownik języka polskiego, t. 1-11, Warszawa 19581969.

Kadulska I. (oprac.), Teatr jezuicki XVIII i XIX wieku w Polsce. Z antologia dramatu, Gdańsk 1997.

Lewińska A., Młodzież szkolna daje przykład-wycinki prasowe w kronikach szkół wiejskich (na przykładzie powiatów tczewskiego, starogardzkiego i malborskiego), „Media. Biznes. Kultura” 2017, nr 1 (2).

Lewińska A., Powojenne kroniki szkół wiejskich jako źródło do badań językoznawczych, „Linguistica Bidgostiana. Series Nowa” 2018, vol. III, Warszawa.

Linde S.B., Stownik języka polskiego, t. 1-6, Warszawa 1994.

Lipski S., Strajk szkolny 1900/7/1907 r. w powiecie starogardzkim, Starogard Gdański 2006.

\section{Netografia}

http://wsjp.pl/index.php?pwh=0

https://opoka.org.pl/biblioteka/T/TA/TAL/ur nspj.html

https://www.polskieradio.pl/39/156/Artykul/1755398,Jan-TadeuszStanislawski---profesor-mniemanologii-stosowanej

http://sjp.pwn.pl

http://www.encyklopediateatru.pl/hasla/281/teatr-jezuicki

https://opoka.org.pl/biblioteka/T/TA/TAK/historia_katechezy.html

https://repozytorium.umk.pl/bitstream/handle/item/1625/Swieto\%20oświaty $\% 20$ popraw.pdf? sequence $=1$

${ }^{12} \mathrm{O}$ kronikach jako materiale do badań językoznawczych - por.: A. Lewińska, Powojenne kroniki szkót wiejskich jako źródło do badań językoznawczych, „Linguistica Bidgostiana. Series Nowa” 2018, vol. III, Warszawa, s. 171-182. 


\section{Skróty}

O - kronika szkoły w Ocyplu

MG - kronika szkoły w Małym Garcu

MS - kronika szkoły w Małej Słońcy

LM - kronika szkoły w Lisewie Malborskim

SJPD - Doroszewski W. (red.), Słownik języka polskiego, t. 1-11, Warszawa 1958-1969.

WSJP - http://wsjp.pl/index.php?pwh=0

L - Linde S.B., Słownik języka polskiego, t. 1-6, Warszawa 1994.

\section{Streszczenie}

\section{Motywy religijne w kronikach szkół wiejskich w latach 1945-1958 (na przykładzie Kociewia i Żuław)}

Powojenne kroniki szkół wiejskich Kociewia i Żuław z lat 1945-1958 są w niewielkim stopniu nasycone motywami religijnymi. Występują one przede wszystkim we wpisach związanych ze szkolnymi obchodami świąt, a zwłaszcza Bożego Narodzenia. Pozostałe opisane w kronikach obszary szkolnej działalności tylko w skromnym zakresie nawiązują do religijnego wymiaru życia ówczesnej wsi.

W dokumentach sporządzanych przez pracowników szkoły w latach 19451957 odbija się laicyzacja powojennej edukacji. Analiza językowa pozwala zaobserwować, jak ówczesne władze starały się zapełnić pustkę po rugowanym życiu duchowym nowymi symbolami i rytuałami oraz jak w wiejskich szkołach rodziła się „nowa świecka tradycja” i tworzył się dla tej tradycji nowy język.

\section{Summary}

\section{Religious motifs in village schools' chronicles in the years 1945-1958 (examples from Kociewie and Żulawy)}

The post-war chronicles from village schools in Kociewie and Żuławy over the period 1945-1958 are only slightly saturated with religious motifs which in the school chronicles are usually present in the entries related to schools' celebrations of holidays, Christmas in particular. The rest of school activity areas specified in the chronicles relate to religious dimension of life in the countryside at that time to a lesser extent.

In the documents drawn up by school staff in the years 1945-1957 the secularization of post-war education is reflected. The linguistic analysis allows to 
observe that the then authorities were trying to fulfill the emptiness after the spiritual life had been weeded out with new symbols and rituals. We can also see that in the village schools a 'new secular tradition' was coming to life together with a new language established for that tradition. 